\title{
Rhinoceros-related delayed traumatic diaphragmatic rupture
}

\author{
Michael Sebastian, M.D., ${ }^{1}$ 실 Alia Abdullah, M.D., ${ }^{1}$ \\ Mohamed Abusharia, M.D., ${ }^{1}$ () Fikri M Abu-Zidan, M.D. ${ }^{2}$
}

\author{
1Department of Surgery, Al-Ain Hospital, Al-Ain-United Arab Emirates \\ ${ }^{2}$ Department of Surgery, College of Medicine and Health Sciences, UAE University, Al-Ain-United Arab Emirates
}

\begin{abstract}
Animal-related injuries should be analyzed based on the behavior and anatomy of the attacking animal. Rhinoceros-related injuries in humans are extremely rare. Hereby, we report a life-threatening traumatic diaphragmatic hernia in a woman who presented three years after a rhinoceros gored her chest.A 47-year-old lady presented with abdominal pain, bilious vomiting and obstipation of one-day duration. She had recurrent attacks of colicky abdominal pain for a week before that. The patient gave the history of being admitted to the ICU three years before, after being gored by a rhinoceros into her chest while working as a veterinary assistant in the zoo. On examination, the abdomen was distended but soft and lax. Bowel sounds were exaggerated.Abdominal x-rays showed multiple air-fluid levels. A gastrographin follow through study hold up in the small bowel and did not reach the colon after seven hours. Abdominal and chest CT scan showed the splenic colonic flexure to be located in the left chest through a left diaphragmatic hernia. Urgent laparotomy showed a healthy splenic flexure of the colon that herniated through a $4 \mathrm{~cm}$ postero-lateral defect in the left diaphragm. The colon was reduced, and the defect was repaired with non-absorbable sutures. Postoperative recovery was smooth. The patient was discharged home 10 days after the surgery. Rhinoceros-related injuries in humans are extremely rare. Life-threatening traumatic diaphragmatic herniation may be delayed for few years. High index of suspicion is needed for its diagnosis.
\end{abstract}

Keywords: Injury; rhinoceros; rupture diaphragm; trauma.

\section{INTRODUCTION}

Rhinoceros-related injuries of humans are extremely rare. In general, animal-related injuries should be analyzed based on the behavior and anatomy of the attacking animal. ${ }^{[1,2]}$ Although rhinoceroses cause approximately $20 \%$ of human injuries, ${ }^{[3]}$ and $30 \%$ of the human fatalities related to wildlife animal attacks, ${ }^{[4]}$ very little is known about the mechanism of these injuries. There is only one case report in the literature describing this mechanism. ${ }^{[5]}$ Herein, we report a life-threatening traumatic diaphragmatic hernia in a woman who presented three years after a rhinoceros gored her chest.

\section{CASE REPORT}

A 47-year-old woman presented to the Emergency Department of Al-Ain Hospital with acute abdominal pain, bilious vomiting and obstipation of one-day duration. She had mild recurrent attacks of colicky abdominal pain for one week. The patient gave a history of being admitted to an Intensive Care Unit, three years before, after being gored by a white rhinoceros into her chest while working as a veterinary assistant in the zoo. She sustained left hemothorax and multiple left rib fractures, which needed chest tube drainage. The patient had a history of appendectomy during her childhood. On examination, the abdomen was distended but soft and

Cite this article as: Sebastian M, Abdullah A, Abusharia M, Abu-Zidan FM. Rhinoceros-related delayed traumatic diaphragmatic rupture.

Ulus Travma Acil Cerrahi Derg 2020;26:486-488.

Address for correspondence: Fikri M Abu-Zidan, M.D.

POBox 17666 AL-Ain - United Arab Emirates.

Tel: 0097|37।37579 E-mail: fabuzidan@uaeu.ac.ae

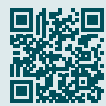

Ulus Travma Acil Cerrahi Derg 2020;26(3):486-488 DOI: 10.14744/tjtes.2019.73857 Submitted: 15.04.2019 Accepted: 29.05.2019 Online: I4.05.2020

Copyright 2020 Turkish Association of Trauma and Emergency Surgery 

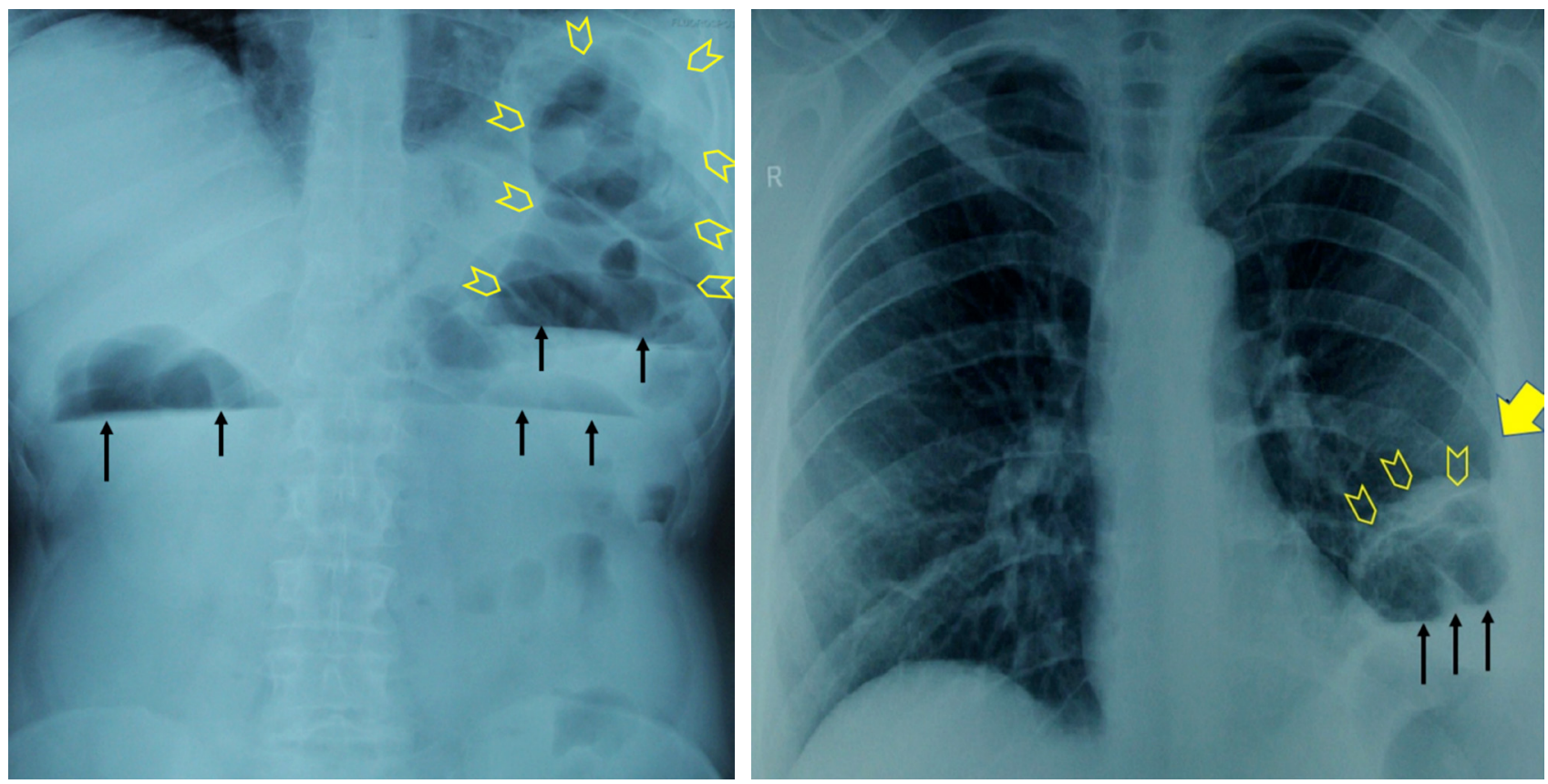

Figure 1. (a) Erect abdominal X-ray showing air-fluid levels (black arrows). A gas-filled structure with haustrations that is continuous with the abdomen (arrowheads) reaches above the left diaphragm suggesting a left diaphragmatic hernia containing part of the colon. (b) An erect chest X-ray taken at the same time showing healed old rib fractures (yellow arrow) with callus formation, air-fluid levels within the colon (black arrows), and compressed lung (arrowheads).

lax. Bowel sounds were exaggerated. Abdominal X-rays showed multiple air-fluid levels and gas-filled structure with haustrations above the left diaphragm, suggesting a left diaphragmatic hernia containing part of the colon (Fig. Ia). Erect chest X-ray taken at the same time showed healed old

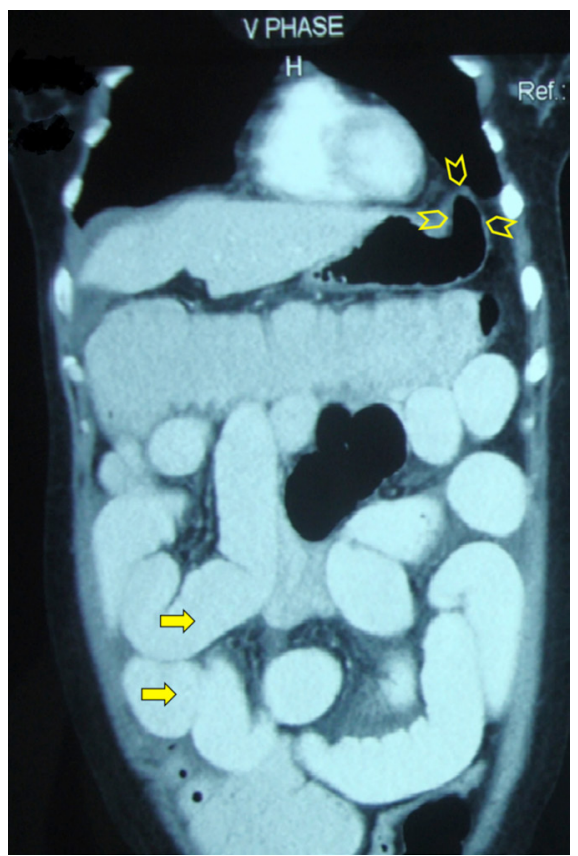

Figure 2. Coronal reconstruction of abdominal CT scan with intravenous and oral contrast showing dilated small bowel (yellow arrows) and transverse colon, and a herniated left splenic flexure of the colon (arrowheads) through the left diaphragm. There was no dye seen in the descending or sigmoid colon. rib fractures with callus formation, air-fluid levels within the colon, and compressed lung (Fig. Ib). A gastrografin followthrough study, hold up in the transverse colon and did not reach the descending colon after seven hours. The abdominal and chest CT scan showed the splenic flexure of the colon to be in the left chest through a left diaphragmatic hernia (Fig. 2). Urgent laparotomy showed a healthy splenic flexure of the colon that herniated through a $4 \mathrm{~cm}$ postero-lateral defect in the left diaphragm. The colon was reduced, and the defect was repaired with non-absorbable sutures. Postoperative recovery was smooth. The patient was discharged home 10 days after surgery. The patient gave her written consent to publish her medical data with the understanding that her identity shall remain confidential.

\section{DISCUSSION}

Animal-related injuries should be analyzed depending on the anatomy and behavior of the attacking animal. The rhinoceros is historically connected to head and neck surgery. The first parathyroid gland was discovered by Sir Richard Owen in 1849 by dissecting a rhinoceros in London Zoological Gardens. ${ }^{[6]}$ Rhinoceroses are large animals reaching up to 3800 $\mathrm{kg}$ in weight. They can be seriously aggressive and dangerous even with the slightest provocation because they have poor vision. ${ }^{[5,7]}$ Both the Indian and African rhinoceroses have 20$100 \mathrm{~cm}$ long single horns that are used as lethal weapons. ${ }^{[3]}$ Accordingly, rhinoceroses have no natural predators. ${ }^{[6]}$ Male rhinoceroses protect their exclusive non-overlapping territories that they mark by the smell of their own urine and stool. ${ }^{[7,8]}$ Dominant male rhinoceroses wipe their horns to trees or 
ground and then attack each other from a distance by touching their horns while their heads and ears are raised up. ${ }^{[7,9]}$

The reaction of rhinoceros to humans varies. It depends mainly on sensory responses. The animal usually prefers not to attack humans but to run for a few hundred meters before stopping. ${ }^{[8]}$ The rhinoceros-related human injury, which was reported by Shah et al., ${ }^{[5]}$ was mainly a goring penetrating chest injury that caused a large left open wound. Our patient presented with a life-threatening left traumatic diaphragmatic hernia three years after the initial rhinoceros-related injury. Our patient was also injured in the chest, possibly because the chest was at the level of the rhinoceros' horn. We have previously reported that the chest was the most common injured human region following camel kicks. We attributed that to the height of the camel kick. ${ }^{[10]}$ Rhinoceroses may also bite humans by the incisors of their lower jaw if humans closely approach them. ${ }^{[8]}$

Our patient presented with a clinical picture of mechanical intestinal obstruction. The patient had a history of appendectomy, raising the suspicion of adhesive intestinal obstruction. However, properly reading the abdominal and chest $X$-rays, and correlating it with the associated history of severe chest trauma, directed us to the diagnosis of delayed diaphragmatic hernia.

\section{Conclusion}

Rhinoceros-related injuries in humans are extremely rare. Life-threatening traumatic diaphragmatic herniation may be delayed for a few years. The high index of suspicion is needed for its diagnosis.

Informed Consent: The patient gave her written consent to publish her medical data with the understanding that her identity shall remain confidential.

Peer-review: Internally peer-reviewed.

Authorship Contributions: Concept: M.S., A.A., M.A., F.A.Z. Design: M.S., A.A., M.A., F.A.Z. Supervision: F.A.Z.; Materials: M.S., A.A., M.A.; Data: M.S., A.A., M.A.; Analysis: M.S., A.A., M.A., F.A.Z. Literature search: F.A.Z.; Writing: F.A.Z.; Critical revision: M.S., A.A., M.A., F.A.Z.

Conflict of Interest: None declared.

Financial Disclosure: The authors declared that this study has received no financial support.

\section{REFERENCES}

1. Abu-Zidan FM, Eid HO, Hefny AF, Bashir MO, Branicki F. Camel bite injuries in United Arab Emirates: a 6 year prospective study. Injury 2012;43:1617-20. [CrossRef]

2. Abu-Zidan FM. Crossroad between camel bites and crocodile bites. Afr Health Sci 2015;15:i-iv. [CrossRef]

3. Acharya KP, Paudel PK, Neupane PR, Köhl M. Human-Wildlife Conflicts in Nepal: Patterns of Human Fatalities and Injuries Caused by Large Mammals. PLoS One 2016;11:e0161717. [CrossRef]

4. Silwal T, Kolejka J, Sharma RP. Injury Severity of Wildlife Attacks on Humans in the Vicinity of Chitwan National Park, Nepal. J Biodivers Manage Forestry 2016; 5:1. [CrossRef]

5. Shah S, Marharjan N, Pradhan S, Kafle P, Chapagain D, Reddy D. A lethal chest injury following rhinoceros attack- a case report. J College Med Sciences-Nepal 2012;8:52-5. [CrossRef]

6. Felger EA, Zeiger MA. The death of an Indian Rhinoceros. World J Surg 2010;34:1805-10. [CrossRef]

7. Owen-Smith N. Territoriality in the white rhinoceros (Ceratotherium simum) Burchell. Nature 1971;231:294-6. [CrossRef]

8. Hutchins M, Kreger MD. Rhinoceros behavior: implications for captive management and conservation. Int Zoo Yb 2006;40:150-73. [CrossRef]

9. Yadav VK. Male-male Aggression in Rhinoceros Unicornis- An observation from North Bengal, India. Zoo's Print J 2000;15:328-30. [CrossRef]

10. Abu-Zidan FM, Hefny AF, Eid HO, Bashir MO, Branicki FJ. Camelrelated injuries: prospective study of 212 patients. World J Surg 2012;36:2384-9. [CrossRef]

\section{OLGU SUNUMU - ÖZET}

\section{Gergedanın neden olduğu gecikmiş travmatik diyafragma rüptürü}

\section{Dr. Michael Sebastian, ${ }^{1}$ Dr. Alia Abdullah, ${ }^{1}$ Dr. Mohamed Abusharia, ${ }^{1}$ Dr. Fikri M Abu-Zidan ${ }^{2}$}

${ }^{1}$ Al-Ain Hastanesi, Genel Cerrahi Bölümü, Al-Ain-Birleşik Arap Emirlikler

${ }^{2}$ BAE Üniversitesi Tıp ve Sağlık Bilimleri Koleji, Genel Cerrahi Anabilim Dalı, Al-Ain-Birleşik Arap Emirlikleri

Hayvanların neden olduğu yaralanmalar, saldıran hayvanın davranışına ve anatomisine dayanarak analiz edilmelidir. İnsanlarda gergedanla ilgili yaralanmalar son derece nadirdir. Bu vesileyle, bir gergedan tarafından göğsünden boynuz darbesi aldıktan üç yıl sonra başvuran kadın hastada yaşamı tehdit eden travmatik diyafragma hernisi olgusunu bildiriyoruz. Kırk yedi yaşında kadın hasta karın ağrısı, safralı kusma ve bir günlük obstipasyon ile başvurdu. Önceden bir hafta boyunca tekrarlayan kolik tarzında karın ağrısı atakları geçirmişti. Hastadan üç yı önce hayvanat bahçesinde veteriner asistanı olarak çalışırken göğsüne bir gergedan tarafından boynuz darbesi aldığını ve yoğun bakım ünitesine kabul edildiği öğrenildi. Muayenede karın şişkin, yumuşak ve gevşekti. Bağırsak sesleri abartılıdı. Batın grafileri çoklu hava sıvı seviyeleri gösterdi. Röntgen çekimi sırasında takip edilen gastrografin kontrast maddesi ince bağırsakta takılıp kaldı ve yedi saat sonra bile kolona ulaşmadı. Abdominal ve torasik bilgisayarlı tomografi taraması, kolonun splenik fleksurasının sol göğüste sol diyafragma fitığı içine yerleşmiş olduğunu gösterdi. Acil laparotomide sol diyaframda $4 \mathrm{~cm}$ 'lik postero-lateral defekt içine fıtıklaşan kolonun splenik fleksurasının sağlıklı olduğu görüldü. Bu kolon segmenti redükte edildi ve defekt emilemeyen sütürlerle onarıldı. Ameliyat sonrası iyileşme sorunsuzdu. Hasta ameliyattan 10 gün sonra taburcu edildi. İnsanlarda gergedanın neden olduğu yaralanmalar son derece nadirdir. Yaşamı tehdit eden travmatik diyafragma hernisi birkaç yıl ertelenebilir. Tanısı için şüphe indeksinin yüksek düzeyde olması gereklidir.

Anahtar sözcükler: Gergedan; rüptüre diyafram; travma; yaralanma.

Ulus Travma Acil Cerrahi Derg 2020;26(3):486-488 doi: 10.14744/tjtes.2019.73857 